\title{
Method validation for determination of metals in Vitis labrusca L. grapevine leaf extracts by inductively coupled plasma mass spectrometry (ICP-MS)
}

\author{
LIANE V.V. BOKOWSKI', ROBERTO B. SOBRINHO ${ }^{2}$, CRISTIÁN J.V. ARMIJO', \\ CAROLINE DANI ${ }^{1}$, JOÃO A.P. HENRIQUES ${ }^{3,4}$ and CLÁUDIA FUNCHAL ${ }^{1}$ \\ ${ }^{1}$ Centro Universitário Metodista - IPA, Rua Cel. Joaquim Pedro Salgado, 80, \\ Bairro Rio Branco, 90420-060 Porto Alegre, RS, Brazil \\ ${ }^{2}$ Instituto Federal Sul-Rio-Grandense, Av. Copacabana, 100, Bairro Piratini, 93216-120 Sapucaia do Sul, RS, Brazil \\ ${ }^{3}$ Departamento de Biofísica, Centro de Biotecnologia, Universidade Federal do Rio Grande do Sul, \\ Av. Bento Gonçalves, 9500, Bairro Agronomia, 91501-970 Porto Alegre, RS, Brazil \\ ${ }^{4}$ Instituto de Biotecnologia, Universidade de Caxias do Sul, Rua Francisco Getúlio Vargas, 1130, \\ Campus Universitário de Caxias do Sul, 95070-560 Caxias do Sul, RS, Brazil
}

Manuscript received on July 7, 2016; accepted for publication on September 5, 2016

\begin{abstract}
Vitis labrusca L. is the main species used for wine and juice production in Brazil. The grapevine leaves can be used both as functional foods and as cheapest sources for the extraction of phenolic compounds. Besides the antioxidant activity, grapevine leaves exhibited significant anti-inflammatory activity. Therefore, the aim of this study was to develop and validate an analytical methodology to determine the metals selenium $\left({ }^{96} \mathrm{Se}\right)$, chromium $\left({ }^{53} \mathrm{Cr}\right)$, nickel $\left({ }^{62} \mathrm{Ni}\right)$, cadmium $\left({ }^{111} \mathrm{Cd}\right)$ and lead $\left({ }^{206} \mathrm{~Pb}\right)$ in 30 samples of grapevine leaf extracts (Vitis labrusca, Bordo cultivar) using inductively coupled plasma mass spectrometry (ICP-MS). To obtain the grapevine leaf extracts the samples were milled, weighed and digested in microwave oven with nitric acid. The method showed linearity, precision, accuracy and limits of quantification and detection acceptable for INMETRO protocol validation of analytical methods. Therefore, the method using ICP-MS was developed and validated to determine metals concentrations in grapevine leaves of Vitis labrusca $\mathrm{L}$. and the proposed method could be applied in routine analytical laboratory.
\end{abstract}

Key words: ICP-MS, Metals, Method validation, Vitis labrusca L.

\section{INTRODUCTION}

Nowadays, the process of method validation has been intensified in order to achieve a high level of quality (Araujo 2008). The criteria used to obtain results in the area of analytical chemistry are progressively more intense due to an increasing necessity to ensure that the results obtained from

Correspondence to: Cláudia Funchal

E-mail: claudia.funchal@metodistadosul.edu.br /

csfunchal@yahoo.com.br researches present safety and reliability (Araujo 2008). This process aims to confirm that the method applied is appropriated. Non-standard methods, methods created and/ or developed by the laboratory, standard methods used outside the traditional scopes, extensions and modifications of standard methods must be validated by the laboratory (EURACHEM 1998, ISO 5725-1 1994, ISO 5725-2 1994/1998, ISO 5725-3 1994/2001, ISO 5725-4 1994, ISO 5725-6 1994/2001). The 
process of validation should be performed with equipment and instruments within specification, working correctly and properly calibrated (INMETRO 2011, Leite 2000, Ribani et al. 2004, NBR ISO/IEC 17025 2005).

Heavy metals presented in soil of technologically advanced agricultural regions could be increased by the use of fertilizers, atmospheric deposition, pesticides application, organic and inorganic solid waste, animal manure application, sewage and contaminated water used for irrigation (Nicholson et al. 2003, He et al. 2005, Karlsson et al. 2010, Nayek et al. 2010). In this context, a technique which is appropriated for the determination of metallic elements is the inductively coupled plasma mass spectrometry (ICP-MS). This methodology is very promising in the area of environmental studies since several elements can be determined using this technique which is highly sensitive for ion detection (Sesi et al. 1997, Broekaert 2002, Santos and Nóbrega 2006).

Vitis labrusca $\mathrm{L}$. is the main species used for wine and juice production in Brazil (Dani et al. 2007) for economic reasons and environmental concerns, growing interest of industrial crops, the large amount of by-products and wastes that are generated in the agricultural sector (Prozil et al. 2012, Spigno et al. 2008). Thus, in some European countries the leaves of Vitis vinifera L. have been traditionally used as food, both in fresh as salted forms (Orhan et al. 2007). Also, grapevine leaves can be used both as functional foods and as inexpensive sources for phenolic compound extraction. Moreover, there is a positive correlation between the concentration of phenolic compounds and ascorbic acid on the grapevine leaves and the antioxidant activity of the main grape variety grown in Brazil (Vitis labrusca L.) (Oliboni et al. 2009, Wohlenberg et al. 2014). Besides antioxidant effect, grapevine leaves presented significant antiinflammatory activity (Scola et al. 2009).
Considering that the mineral content and metal contamination in grape juices from Vitis labrusca L. (Concord, Isabel and Bordo) was already determined by ICP-MS (Toaldo et al. 2013) the aim of this study was to develop and validate an analytical methodology to determine the metals nickel $\left({ }^{62} \mathrm{Ni}\right)$, cadmium $\left({ }^{111} \mathrm{Cd}\right)$, Lead $\left({ }^{206} \mathrm{~Pb}\right)$, chromium $\left({ }^{53} \mathrm{Cr}\right)$, and selenium $\left({ }^{96} \mathrm{SeO}\right)$, in grapevine leaf extracts of Vitis labrusca (Bordo cultivar) using ICP-MS.

\section{MATERIALS AND METHODS}

\section{CHEMICALS}

Concentrated nitric acid $\left(\mathrm{HNO}_{3 ;}, 65 \%-69 \%\right)$ was purchased from Baker (Center Valley, USA) 9598-34 (lot 10038); Milli-Q water; hydrogen peroxide $\left(\mathrm{H}_{2} \mathrm{O}_{2} ; 30 \% \mathrm{v} / \mathrm{v}\right)$ from Merck (Darmstadt, Germany); 1.07210 .1000 (lot k41660010); argon gas type $4.8-99.998 \%$ min and oxygen gas type 6.0 - 99.9999\% min were purchased from White Martins (Porto Alegre, Brazil); certified standard solution of $\mathrm{Ni}-1000 \mathrm{mg} / \mathrm{mL}$ (lot 122607), certified standard solution of $\mathrm{Cr}-1000 \mathrm{mg} / \mathrm{mL}$ (lot 72408), certified standard solution of $\mathrm{Pb}-1000 \mathrm{mg} / \mathrm{mL}$ (lot 71108), certified standard solution of Cd - $1000 \mathrm{mg}$ / $\mathrm{mL}$ (lot 72408), certified standard solution of Se$1000 \mathrm{mg} / \mathrm{mL}$ (lot 52208) were from Absolute Grade TM . The all standard solutions were purchased from the National Institute of Standards and Technology (NIST) (Gaithersburg, USA).

\section{EQUIPMENTS}

The samples were milled and homogenized in planetary mill, type PM 400, in cups of yttriumstabilized zirconia, with spheres of small bottles with five balls. They were treated by static charge eliminator - Chapman Model VSE3000. Samples were submitted to digestion by microwave MARS 5 - XPress and accessories. Analysis of the samples were subjected to determination by ICP-MS, Perkin Elmer Sciex Elan II DRC (Concord, Ontario, Canada). 


\section{ICP-MS CONDITIONS}

The determination of the metals in the samples was determined by ICP Mass Spectrometer ELAN DRC II Perkin Elmer composed of ultra-clean needle, autosampler AS 93 plus, copper coil RF, mist chamber cyclonic, sampler cone, skimmer cone, air filter, injector quartz, ion lens; Meinhard nebulizer, recirculating, quartz torch, nebulizer tube adapter, tube to the drain of $3.18 \mathrm{~mm}$ tube for the sample of $0.76 \mathrm{~mm}$ tube autosampler.

\section{PREPARATION OF STANDARD SOLUTIONS}

The working curve was prepared from intermediate solutions with certified solutions of $\mathrm{Ni}, \mathrm{Cd}, \mathrm{Pb}$, $\mathrm{Cr}$, and $\mathrm{Se}$. The solutions were transferred by micropipette to $50 \mathrm{~mL}$ flasks. The flasks were previously identified and contained $\mathrm{HNO}_{3}$ and Milli-Q water. The aliquots of each metal of interest were previously calculated.

\section{PREPARATION OF SAMPLES}

The samples used were extracts of grapevine leaves of Vitis labrusca L. (Bordo cultivar). These samples were collected from vineyards at Flores da Cunha, Serra Gaucha on the state of Rio Grande do Sul, Brazil. The sample collected from Vitis labrusca were milled and homogenized in planetary mill. The samples were ground for 22 minutes at 335 rpm. Each sample contained $150 \mathrm{mg}$. The samples were digested using a digestion tube Xpress, which was treated by static charge eliminator (not heated) before weighing to avoid any adherence of the samples to the tube digestion walls. Next, the samples were weighed directly into the digester tube. To the digester tube containing the weighed samples were added $\mathrm{HNO}_{3}$ aiming to release the adhered metal, and $\mathrm{H}_{2} \mathrm{O}_{2}$ to assist in clarifying the extract obtained.

Subsequently, the tubes containing the acid solution were submitted to digestion by microwave. It was allowed the cooling tubes digesters to complete depressurization. Each sample of digested
Vitis labrusca L. was transferred quantitatively to a $50 \mathrm{~mL}$ bottle Sarstedt, properly identified. It was completed the volume of the bottle with Milli-Q water up to the mark of $50 \mathrm{~mL}$ and homogenized. Along with samples it was prepared a blank of process through all stages of preparation, except to weigh. The conditions of temperature and humidity during the analysis were monitored and maintained at about $22 \pm 2{ }^{\circ} \mathrm{C}$ and $60 \pm 5 \%$, respectively, according to (ISO $33082000 \mathrm{E}$ ) to eliminate any contribution from environmental conditions. The method was an adaptation of the method $\mathrm{T}-306$, Health Canada-Official Method.

\section{VALIDATION METHOD}

The validation parameters included in this study were linearity, accuracy, precision, detection limit (DL), and limit of quantification (LOQ). The validation method followed the protocol guidelines on validation of analytical methods (INMETRO 2011).

\section{Linearity}

Linearity is the range that is possible to obtain results of analysis directly or by a mathematical transformation, proportional to the analyte concentration over the range stipulated. The equation of the calibration curve that relates the dependent (y) and independent ( $\mathrm{x}$ ) variables is $y=a x+b$. The mathematical method known as linear regression was used to estimate the coefficients of the calibration curve, from one set of experimental measurements. The value of 0.99 was used for the coefficient of correlation $\left(\mathrm{r}^{2}\right)$ as the limit for setting the coefficients of the curve.

\section{Accuracy}

Accuracy of an analytical method, also called recovery, is defined as the closeness between the true value of the analyte in the sample and the value obtained by the analytical procedure. It is a 
parameter that ensures that no loss or contamination occurred during the test procedure, contributing to quantify the compounds. From a sample with low metal content, was held spikes with 3 different levels of analyte. The samples were subjected to the highest possible steps of the procedure for at least three days with two replicates per day. It was calculated the mean, standard deviation, relative standard deviation (RSD) and recovery (\%Rec), where $\mathrm{C}_{\mathrm{spk}}$ is the analyte concentration in the sample spiked; $\mathrm{C}_{\text {ref }}$ is the analyte concentration in the unfortified sample; $\mathrm{C}_{\text {add }}$ is the analyte concentration in the sample added. Mathematically, the $\% \mathrm{Rec}$ is defined as in Equation (1).

$\% \operatorname{Rec}=\frac{\mathrm{C}_{\text {spk. }}-\mathrm{C}_{\text {ref }}}{\mathrm{C}_{\text {add }}} \times 100$

\section{Precision}

Precision is also an analytical parameter called variability. It expresses the variations within the same laboratory, when the same sample is analyzed by the same procedure, by instrument and/or different analysts in different time interval. We chose a sample with low metal content for all modeled elements and the addition of spikes in three concentration levels. One analyst was selected to analyze samples of Vitis labrusca L., on different days. It was calculated the mean equation (2), standard deviation (SD) equation (3) and relative standard deviation (RSD) equation (4).

$\bar{X}=\frac{\sum_{i=1}^{n} X_{i}}{n}$

$S D=\sqrt{\frac{\sum_{i=1}^{n}\left(X_{i}-\bar{X}\right)}{n-1}}$

$R S D=\frac{S D}{\bar{X}}$

\section{Detection limit $(D L)$}

DL is the lowest concentration that can be distinguished from noise, but not necessarily quantified. The DL of this method was established by analyzing the sample SD of the low content through the entire analytical process, a total of 10 repetitions was performed. The limit has been studied as three times SD, according to the equation (5).

$D L=3 \times S D$

\section{Limit of quantification (LOQ)}

LOQ is defined as the lowest concentration of analyte in a sample that can be determined with acceptable precision and accuracy. The LOQ was studied in the same way as LOD being set as ten times the SD, according to the equation (6).

$L O Q=10 \times S D$

\section{STATISTICAL ANALYSIS}

The study of 30 samples of grapeleaf extracts of Vitis labrusca L. was performed with each of the elements of interest. The data of mean, SD and coefficient of variation are presented. The analyzes were be performed using Statistical Package for Social Sciences (SPSS) software versão19.0.

\section{RESULTS AND DISCUSSION}

In order to develop a method for determining metals by ICP-MS initially it was necessary to ensure optimal conditions for equipment calibration according to the parameters recommended by the equipment guide (Mestek et al. 2002, Perkin Elmer 2007, D'llio et al. 2007). The monitoring of these parameters certified that the equipment was able to carry out sample reading. These evaluations should be done daily for the checking of the ICPMS system and verification of the correlation coefficient of the calibration method (INMETRO 2011, Perkin Elmer 2007, Darrouzés et al. 2006). 
The verification of ICP-MS system measured the performance of this equipment by injecting a certified solution indicated by the manufacturing Perkin Elmer. This procedure was used to assess the equipment and its sensitivity and the percentage of cerium oxide $(\mathrm{CeO} / \mathrm{Ce})$. Moreover, the sensitivity of the equipment was measured by the number of counts determined for the Indian $\left({ }^{114} \mathrm{In}\right)$, being the recommended In $>25000$. This element was chosen as a reference because its mass is intermediate from the elements determined in this study $\left({ }^{96} \mathrm{SeO},{ }^{53} \mathrm{Cr}\right.$, ${ }^{62} \mathrm{Ni} ;{ }^{111} \mathrm{Cd} ;{ }^{206} \mathrm{~Pb}$ ). When the number of In counts was satisfactory, it means that the equipment had adequate sensitivity to determine the elements of interest. As tools of adjustments to achieve the ideal conditions in order to consider that the ideal profile optimization of ion lens we used $1350 \mathrm{~W}$ and the sampler and skimmer cones were platinum (Table I).

The percentage of $(\mathrm{CeO} / \mathrm{Ce})$ was monitored to ensure better flow of argon gas in the nebulizer in order to reach the recommendation made by Perkin Elmer for this parameter $(\mathrm{CeO} / \mathrm{Ce} \leq 4 \%)$. Moreover, the establishment of this condition provided greater reliability in reading Se in the samples, as it was determined in the form of oxide $(\mathrm{SeO})$. The type of nebulizer was chosen according to the facilitator of this process (Table I).

After reaching all these parameters, that confirm that the equipment was ready for use, we could proceed the injection and subsequent verification of the coefficient of determination of the calibration curve. At this stage we evaluated the coefficient of determination which according to national standard validation protocol (INMETRO 2011) should be $r^{2} \geq 0.99$. The attendance of these parameters was an indicative that the adjustments applied to the equipment were consistent, that the developed method was appropriate and that it had been achieved a safe condition to carry out the method validation (Table I).

Then, we fixed some parameters to establish the final composition of the method such as: time and scan mode, the number of replicates, peak expected for better performance, integration time, waiting time and oxygen flow gas for reading $\mathrm{SeO}$.

The method validation followed the parameters adopted by national standards (INMETRO 2011), which is based in well established methods from EUROCHEM and ISO 57251994 (EURACHEM

TABLE I

Instrument settings and data acquisition parameters for DRC II-ICP-MS.

\begin{tabular}{ll}
\hline Instrument & $1350 \mathrm{~W}$ \\
RF power & Plasma, 15; Auxiliary, 1; Nebulizer, 0,9 - 1,01 (L min -1) \\
Gas flow rates & \\
Interface & Pt cones \\
Sampling and Skimmer & ${ }^{96} \mathrm{SeO} ;{ }^{53} \mathrm{Cr} ;{ }^{62} \mathrm{Ni} ;{ }^{111} \mathrm{Cd} ;{ }^{206} \mathrm{~Pb}$ \\
Analytical mass & 20 \\
Sweeps/reading (s) & 1 \\
Reading/replicate & 3 \\
Replicates & Peak hopping \\
Scan mode & 50 \\
Dwell time per AMU (ms) & 1000 \\
Integration time (ms): & 0 \\
Cell gas A & $1.15(\mathrm{SeO})$ \\
Cell gas B &
\end{tabular}

According to Perkin Elmer Guide. 
1998, ISO 5725-1 1994, ISO 5725-2 1994/1998, ISO 5725-3 1994/2001, ISO 5725-4 1994, ISO 5725-6 1994/2001).

Linearity data was generated by information from the readings of the five points of the calibration curve, which contained all the metals studied in three consecutive days. All the correlation coefficients were in the limit required by national standards (INMETRO 2011), $\left(r^{2} \geq 0.99\right)$, being the

a)

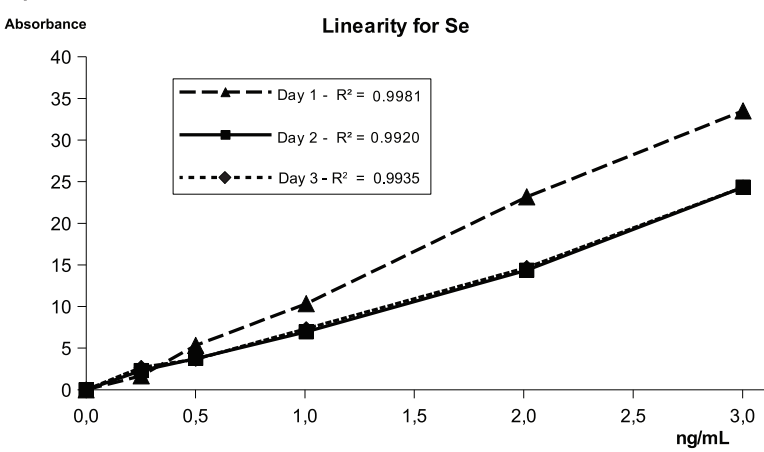

b)

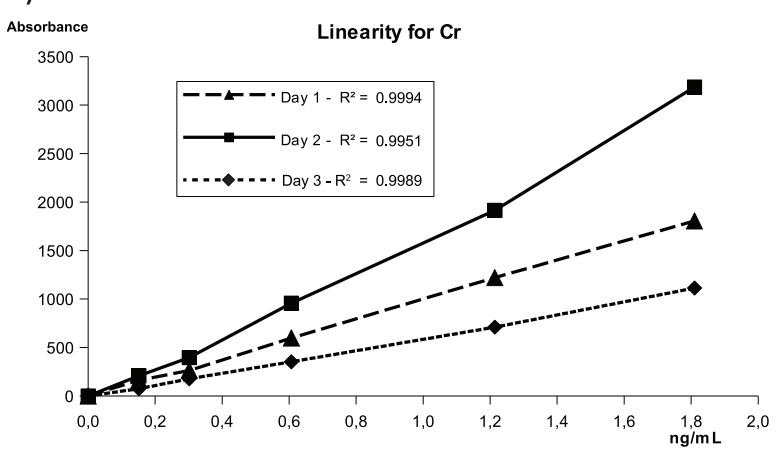

c)

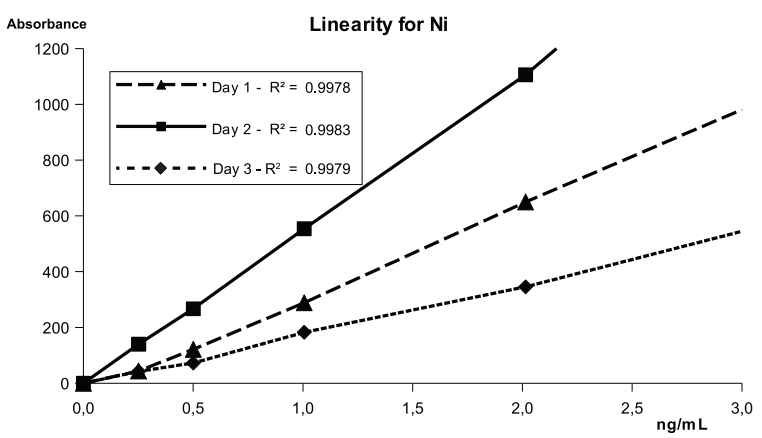

smallest one obtained 0.992 , for $\mathrm{SeO}$, which was above this limit (Figure 1).

Accuracy was obtained by reading the pure sample and three known concentrations $(0.2,0.3$ and $0.4 \mathrm{ng} / \mathrm{mL}$ ) of samples. We evaluated the $\%$ Rec obtained, the results were within the range of $95.5 \%$ (for $\mathrm{Ni}$ ) to $102.4 \%$ (for $\mathrm{SeO}$ ) (Table II). The \% Rec recommended by national standards (INMETRO 2011 ), must be within the range of $80 \%$ to $120 \%$.

e)

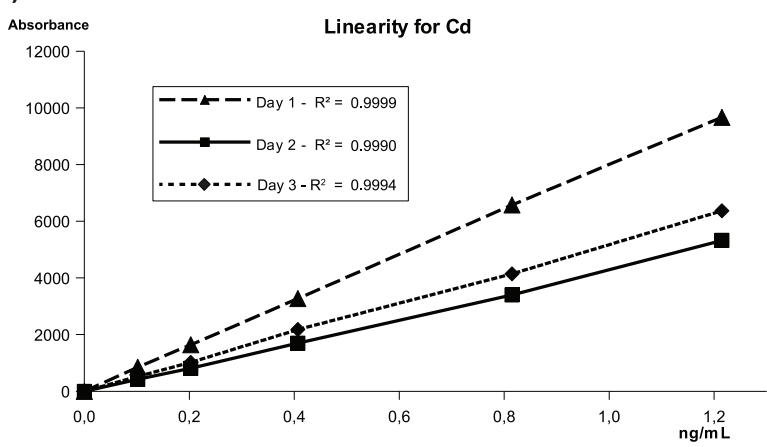

f)

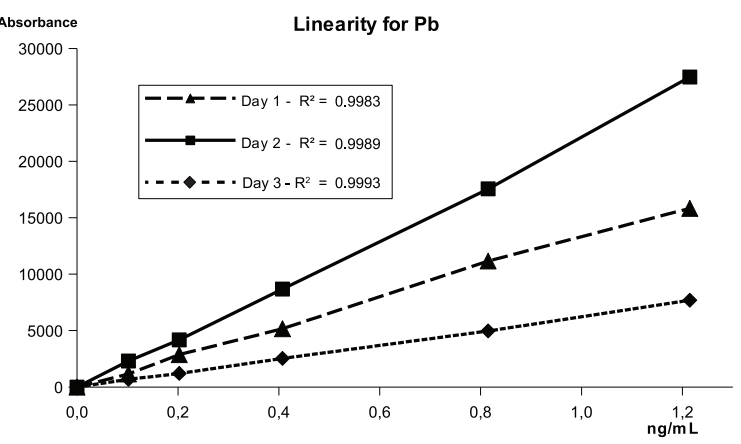

Figure 1 - Linearity data obtained from the readings of calibration curve which contained Standard solution of $\mathrm{Se}(\mathrm{A}), \mathrm{Cr}(\mathrm{B}), \mathrm{Ni}$ (C), $\mathrm{Cd}(\mathrm{D}), \mathrm{Pb}(\mathrm{E})$ in three consecutive days. 
TABLE II

Validation Parameters.

\begin{tabular}{ccccccc}
\hline $\begin{array}{c}\text { Analytics } \\
\mathrm{n}=30^{*}\end{array}$ & $\begin{array}{c}\text { Spike Value } \\
(\mathrm{ng} / \mathrm{mL})\end{array}$ & $\begin{array}{c}\text { \% Recovered } \\
\mathrm{n}=30\end{array}$ & $\begin{array}{c}\text { Average }(\mathrm{ng} / \mathrm{mL}) \\
\mathrm{n}=30\end{array}$ & $\begin{array}{c}\% \\
\mathrm{RSD}^{\mathrm{b}} \\
\mathrm{n}=30\end{array}$ & $\begin{array}{c}\mathrm{LD}^{\mathrm{c}}(\mathrm{ng} / \mathrm{mL}) \\
\mathrm{n}=30\end{array}$ & $\begin{array}{c}\text { LOQ }^{\mathrm{d}}(\mathrm{ng} / \mathrm{mL}) \\
\mathrm{n}=30\end{array}$ \\
\hline \multirow{2}{*}{${ }^{96} \mathrm{SeO}$} & 0.20 & 102.4 & $0.38 \pm 0.037$ & 9.80 & 0.11 & 0.37 \\
& 0.30 & 98.1 & $0.47 \pm 0.037$ & 8.00 & 0.11 & 0.37 \\
& 0.40 & 99.2 & $0.57 \pm 0.040$ & 7.00 & 0.12 & 0.40 \\
${ }^{53} \mathrm{Cr}$ & 0.20 & 101.9 & $0.43 \pm 0.038$ & 9.00 & 0.11 & 0.38 \\
& 0.30 & 100.6 & $0.52 \pm 0.046$ & 8.70 & 0.14 & 0.46 \\
& 0.40 & 101.5 & $0.63 \pm 0.052$ & 8.30 & 0.16 & 0.52 \\
${ }^{62} \mathrm{Ni}$ & 0.20 & 95.5 & $0.69 \pm 0.040$ & 5.70 & 0.12 & 0.40 \\
& 0.30 & 99.6 & $0.80 \pm 0.061$ & 7.60 & 0.18 & 0.61 \\
& 0.40 & 99.7 & $0.90 \pm 0.055$ & 6.10 & 0.17 & 0.55 \\
${ }^{111} \mathrm{Cd}$ & 0.20 & 97.2 & $0.29 \pm 0.017$ & 6.00 & 0.05 & 0.17 \\
& 0.30 & 98.1 & $0.39 \pm 0.020$ & 5.10 & 0.06 & 0.20 \\
& 0.40 & 100.3 & $0.49 \pm 0.021$ & 4.30 & 0.06 & 0.21 \\
${ }^{206} \mathrm{~Pb}$ & 0.20 & 97 & $0.39 \pm 0.034$ & 8.70 & 0.10 & 0.34 \\
& 0.30 & 97.5 & $0.48 \pm 0.030$ & 6.20 & 0.09 & 0.30 \\
& 0.40 & 101.9 & $0.60 \pm 0.042$ & 7.00 & 0.13 & 0.42 \\
\hline
\end{tabular}

${ }^{*} \mathrm{n}=30$ for each spike level was evaluated 10 replicates; ${ }^{\mathrm{a}}$ INMETRO range of $80 \%$ to $120 \%$; ${ }^{\mathrm{b}} \mathrm{RSD}=$ coefficient of variation ; ${ }^{\mathrm{c}} \mathrm{LD}=$ limit of detection; ${ }^{\mathrm{d}} \mathrm{LOQ}=$ limit of quantification.

Precision was obtained using the same procedure for the determination of accuracy. It was calculated the mean, SD and RSD for each of the metals at different levels of spike. It was found that the highest coefficient of variation was $9.8 \%$, in $\mathrm{SeO}$ in first spike (Table II). Although it is not established the appropriate percentage range for the precision, the recommendation of national and international standards is that it is as small as possible within the acceptable limits of the method under study. Within this context the percentage found for accuracy was considered compatible with the methodology by national standards (INMETRO 2011).

$\mathrm{LD}$ for elements $\mathrm{SeO}, \mathrm{Cr}, \mathrm{Ni}, \mathrm{Cd}, \mathrm{Pb}$ were $0.092,0.038,0.033,0.006$ and $0.010 \mathrm{ng} / \mathrm{mL}$, respectively and the LOQ, $0.3082,0.1268,0.1112$, 0.0196 and $0.0323 \mathrm{ng} / \mathrm{mL}$ (Table II). So as the precision, the limits of detection and quantification are specific to each method, being the tracks found here considered acceptable for the method by national standards (INMETRO 2011).

\section{CONCLUSIONS}

A method using ICP-MS was developed and validated to determine metals in grapevine leaf of Vitis labrusca L. (Bordo cultivar). The method showed linearity, precision, accuracy, LD and LOQ acceptable under the validation protocol of INMETRO (2011). These parameters assure that the proposed methodology could be applied in routine analytical laboratory.

\section{ACKNOWLEDGMENTS}

Product Centre Americas Company Souza Cruz, Centro Universitário Metodista - IPA, Coordenação de Aperfeiçoamento de Pessoal de Nível Superior (CAPES) and Conselho Nacional de Desenvolvimento Científico e Tecnológico (CNPq) for the support. The authors would also like to thanks Vinícola Gileoli and ECONATURA for the kindly donation of the grapevine leaves. 


\section{REFERENCES}

ARAUJO P. 2008. Key aspects of analytical method validation and linearity evaluation. J Chromatography B 877: 22242234.

BLUME H, BRENDEL E, BRUDNY-KLÖPPEL M, GREBE S, LAUSECKER B, ROHDE G and SIETHOFF C. 2011. Workshop/Conference Report on EMA Draft Guideline on Validation of Bioanalytical Methods. Europ J Pharm Sciences 42: 300-305.

BROEKAERT JAC. 2002. Analytical Atomic Spectrometry with Flames and Plasmas. Wiley-VCH Verlag $\mathrm{GmbH} \&$ Co. KGaA. ISBNs: 3-527-30146-1. Trend Anal Chem 21: 27-30.

DANI C, OLIBONI LS, BONATTO D, VANDERLINDE R, SALVADOR M and HENRIQUES JAP. 2007. Phenolic content and antioxidant activities of white and purple juices manufactured with organically or conventionally produced grapes. Food Chem Toxicol 45: 2574-2580.

DARROUZÈS J, BUENO M, LESPÈS G, HOLEMAN M AND POTIN-GAUTIER M. 2006. Optimization of ICP MS collision/reaction cell conditions for the simultaneous removal of argon based interferences of arsenic and selenium in water samples. Talanta 71: 2080-2084.

D'ILIO S, VIOLANTE N, SENOFONTE O AND PETRUCCI F. 2007. Determination of depleted uranium in fish validation of a confirmatory method by dynamic reaction cell inductively coupled plasma mass spectrometry (DRCICP-MS). Analytica Chimica Acta 597: 195-202.

EURACHEM. 1998. The fitness for Purpose of Analytical Methods. A laboratory Guide to Method Validation and Related Topics $1^{\text {st }}$ ed.

HE ZL, YANG XE AND ATOFFELLA PJ. 2005. Review: Trace Elements in Agroecosystems and Impacts on the Environment. J Trace Elem Med Biol 19: 125-140.

INMETRO. 2011. Orientação sobre Validação de Métodos Analíticos, Instituto Nacional Metrologia, Normalização e Qualidade Industrial. (INMETRO), www.inmetro.gov.br/ credenciamento/ laboratorios/calibEnsaios.asp (accessed 14/06/2014).

ISO 5725-1. 1994. Accuracy (trueness and precision) of Measurement Methods and Results- Part 1: General principles and definitions.

ISO 5725-2. 1994-1998. Accuracy (trueness and precision) of Measurement Methods and Results- Part 2: basic method for the Determination of Repeatability and Reprodutibility of a Standard Measurement Method.

ISO 5725-3.1994-2001. Accuracy (trueness and precision) of Measurement Methods and Results- Part 3: Intermediate Measures of Precision of a Standard Measurement Method. ISO 5725-4. 1994. Accuracy (trueness and precision) of Measurement Methods and Results- Part 4: Basic Methods for the Determination of the Trueness of a Standard Measurement method.

ISO 5725-6. 1994-2001. Accuracy (trueness and precision) of Measurement Methods and Results- Part 6: Use in Practice of Accuracy Value.

ISO 3308. 2000. (E) - Routine Analytical Cigarette - Smoking Machine Definitions and Standard Conditions.

KARLSSON K, VIKLANDER M, SCHOLES L AND REVITT M. 2010. Heavy metal concentrations and toxicity in water and sediment from stormwater ponds and sedimentation tanks. J Hazar Mater 178: 612-618.

LEITE F. 2000. Validação em Análise Química, 4 ed., Átomo, São Paulo.

MESTEK O, KOMÍNKOVA J, KOPLÍK R, BORKOVÁ M AND SUCHÁNEK M. 2002. Quantification of copper and zinc species fractions in legume seeds extracts by SEC/ ICP-MS: validation and uncertainty estimation. Talanta 57: 1133-1142.

NAYEK S, GUPTA S AND SAHA RN. 2010. Metal accumulation and its effects in relation to biochemical response of vegetables irrigated with metal contaminated water and wastewater. J Hazar Mater 178: 588-595.

NBR ISO/IEC 17025. 2005. Requisitos Gerais para a Competência de Laboratórios de Calibração e de Ensaios, ABNT, Brazil.

NICHOLSON FA, SMITH SR, ALLOWAY BJ, CARLTONSMITH C AND CHAMBERS BJ. 2003. An Inventory of Heavy Metas Inputs to Agricultural Soils in England and Wales. Sci Total Environ 311: 205-219.

OLIBONI L, DANI, C, SALVADOR M AND HENRIQUES JA. 2009. Atividade antioxidante de folhas de parreira de Vitis labrusca. Ciência em Movimento 21: 39-44.

ORHAN DD, ORHAN N AND ERGUN F. 2007. Hepatoprotective effect of Vitis vinifera L. leaves on carbon tetrachloride-induced acute liver damage in rats. J Ethnopharmacol 12: 145-151.

PERKIN ELMER GUIDE. 2007. PERKINELMER/MDS SCIEX Instruments, Version 3.4.

PROZIL SO, EVTUGUIN DV AND LOPES LPC. 2012. Chemical composition of grape stalks of Vitis vinifera $\mathrm{L}$. from red grape pomaces. Ind Crops Prod 35: 178-184.

RIBANI M, BOTTOLI GBC, COLLINS CH, JARDIM FSCI AND MELO CFL. 2004. Validação em métodos cromatográficos e eletroforéticos. Quim Nova vol. $27 \mathrm{n}^{\circ} 5$.

SANTOS M AND NÓBREGA J. 2006. Slurry Nebulization in Plasmas for Analysis of Inorganic Materials. Appl Spectrosc Rev 41: 427-448.

SCOLA G, GAMBATTO G, SPADA PKWDS AND SALVADOR M. 2009. Atividade biológica de semente de uva. Ciência em Movimento 21: 13-20.

SESI NN, HANSELMAN DS, GALLEY P, HORNER J, HUANG M AND HIEFTJE GM. 1997. An imaging-based 
instrument for fundamental plasma studies. Spectroch Acta Part B 52: 83-102.

SPIGNO G, PIZZORNO T AND FAVERI DM. 2008. Cellulose and hemicelluloses recovery from grape stalks. Bioresour Technol 99: 4329-4337.

TOALDO IM, FOGOLARI O, PIMENTEL GC, GOIS JS, BORGES DÇG, CALIARI V AND BORDIHNON-LUIZ M. 2013. Effect of grape seeds on the polyphenol bioactive content and elemental composition by ICP-MS of grape juices from Vitis labrusca L. Food Sci Technol 53: 1-8.

WOHLENBERG M, ALMEIDA D, BOKOWSKI L, MEDEIROS N, AGOSTINI F, FUNCHAL C AND DANI C. 2014. Antioxidant Activity of Grapevine Leaf Extracts against Oxidative Stress Induced by Carbon Tetrachloride in Cerebral Cortex, Hippocampus and Cerebellum of Rats. Antioxidants 3(2): 200-211. 